\title{
Multivariate Analysis of Metal Levels in Paddy Soil, Rice Plants, and Rice Grains: A Case Study from Shakargarh, Pakistan
}

\author{
Saadia R. Tariq and Nabila Rashid \\ Department of Chemistry, Lahore College for Women University, 45600 Lahore, Pakistan \\ Correspondence should be addressed to Saadia R. Tariq; saadiartariq@yahoo.com
}

Received 22 June 2012; Accepted 12 July 2012

Academic Editor: Athanasios Katsoyiannis

Copyright (C) 2013 S. R. Tariq and N. Rashid. This is an open access article distributed under the Creative Commons Attribution License, which permits unrestricted use, distribution, and reproduction in any medium, provided the original work is properly cited.

\begin{abstract}
The present study aims at determining the relationship between trace metal levels in paddy soils, rice plants, and rice grains obtained from these plants. The levels of selected metals ( $\mathrm{Fe}, \mathrm{Co}, \mathrm{Ni}, \mathrm{Cd}, \mathrm{Pb}$, and $\mathrm{Cr}$ ) were determined by atomic absorption spectrophotometry in the soil, rice plants, and rice grain samples collected from paddy fields. All the metals were present at enhanced levels in paddy soil. Among the selected metals, $\mathrm{Fe}, \mathrm{Ni}, \mathrm{Cd}$, and $\mathrm{Cr}$ were predominantly associated with oxidizable fraction. The metals such as $\mathrm{Cr}, \mathrm{Ni}, \mathrm{Co}$, and Fe were significantly positively correlated in soil and plants, but no such correlation was observed in soil-grain matrix evidencing that these metals have a soil-based origin in the plants, but they were not translocated to grains. The $\mathrm{Pb}$ content of soil was strongly positively correlated with plants as well as the grains. The principal component analysis and cluster analysis were used to depict the origin of enhanced metal levels in rice plants. Under the given field conditions, different metals possess different translocation behaviours from soil to roots to shoots to grains. There is a dire need to implement the strategies for wise and optimum use of agrochemicals.
\end{abstract}

\section{Introduction}

The greater urgency to obtain more and more crop yields per capita has led to the excessive use of agrochemicals which not only supply the nutrients to the soils and adjust their $\mathrm{pH}$ but also protect the precious crops from various pests [1]. Despite all these benefits, the excessive and continuous use of agrochemicals may lead to a substantial increase in concentrations of major elements like $\mathrm{K}, \mathrm{Ca}$, and $\mathrm{Mg}$ and heavy metals such as $\mathrm{Cd}$ and $\mathrm{Zn}$ in soil solutions, thereby deteriorating the soil quality with a subsequent effect on plants that show stunted growth and thus lower crop yields [2].

In developing countries, the heavy-metal-contaminated sewage sludges are also used as fertilizers, which on continuous application may lead to the accumulation of toxic metals into the soil. The subsequent uptake of metals in the edible parts of vegetative tissues may result in a direct pathway into the human food chain [3]. Moreover, these metals may leach from contaminated soils into the water bodies thereby deteriorating their quality as well [4]. Therefore, attention has been diverted towards the determination of metal levels in various agricultural soils and their extent of bioavailability to plants due to their detrimental effects on soil flora and fauna and their potential human health risks [5-10].

Rice is a favorite food for more than three billion people around the world [11]. In Pakistan, rice is grown under diverse climatic and edaphic conditions. Paddy soils are specifically of interest because for the cultivation of rice; these soils are kept submerged for longer periods of time, which may cause reduction and subsequent mobilization of various metals such as Fe and Mn [12]. Therefore, paddy soils have been of interest to the scientists for the determination of the levels and sources of heavy metals [1]. Qishlaqi and Moore reported fungicides as major cause of $\mathrm{Cu}$ contamination of agricultural soils [7]. In rice-consuming countries like Iran, rice was suggested as one of the major sources of Cd intake due to high potential of these plants to accumulate $\mathrm{Cd}$ from contaminated soils into their grains [13].

In view of the hazards caused by the accumulation of heavy metals in the soil due to excessive agrochemical usage, the present study was formulated to determine the 
metal contents of soil samples collected from paddy fields of Tehsil Shakargarh, Pakistan, to determine the fractionation of metals present in paddy soils to study their bioavailability and mobility, and then to study the uptake of metals by rice plants and their translocation to edible parts. The study will not only highlight the metal contamination of the paddy fields arising due to excessive and unwise use of agrochemicals but also help to identify the potential risk of elevated levels of these metals to the consumers.

\section{Experimental Methodology}

2.1. Description of Sampling Site. The samples were collected from paddy fields of tehsil Shakargarh of Punjab province of Pakistan. The city is located at $32^{\circ} 16^{\prime} 0 \mathrm{~N} 75^{\circ} 10^{\prime} 0 \mathrm{E}$ on the west bank of the river Ravi, encompassing an area of about $1272 \mathrm{~km}^{2}$. Its rich and fertile lands are well known for wheat and top-quality rice cultivation. The main sources of irrigation in the sampling area are tube wells and electric pumps (water table 40-50 ft). The soil texture here is loamy, which is considered to be best for agricultural purposes because this can be ploughed easily and has tendency to retain good moisture content. Flour mills and rice processing units are the only industries present here.

2.2. Sample Collection and Pretreatment. A total of 35 samples each of top soil $(1-5 \mathrm{~cm})$, rice plants, and rice grains were collected in triplicate in $500 \mathrm{~g}$ capacity from different rice fields located at a distance of $1 \mathrm{~km}$ apart. The samples were properly labeled and immediately transferred to laboratory for analysis.

The collected soil samples were cleaned manually for twigs, roots, stones, or any other foreign matter, homogenised, and dried in an electric oven set at $80^{\circ} \mathrm{C}$ for $24 \mathrm{~h}$. The rice plant samples were thoroughly washed with deionised water, dried in shade, chopped, homogenized, and stored in zip mouthed bags. Similarly, the rice grains after cleaning, washing, and grinding were stored in polythene bottles.

Analytical grade reagents with a certified purity of $99.9 \%$, procured from E. Merck (Germany), were used throughout the work. The stock solutions of metals (1000 ppm) contained in strong opaque polyethylene bottles were also purchased from E-Merck Germany and stored in a cool and dry place.

2.3. Determination of Soil Physicochemical Parameters. The physicochemical parameters of the soil samples were determined by using the water extracts of these samples, prepared by shaking soil sample with deionized, distilled water in $1: 1$ ratio for 5 minutes. Subsequently, the contents were equilibrated for thirty minutes and filtered. The filtrate was used for the determination of physicochemical parameters in accordance with standard methods. The moisture content of the soil samples was determined gravimetrically [14].

2.4. Determination of Metal Contents of Soil Samples. In order to determine the metal contents of soil samples, air-dried and sieved soil samples, $\left(2 \mathrm{~g}\right.$ ) were digested by using $\mathrm{HNO}_{3}$ and $\mathrm{H}_{2} \mathrm{O}_{2}$ [14]. The digested samples were then diluted with distilled water and analyzed for the selected metals by using Hitachi Flame Atomic Absorption Spectrophotometer (FAAS) model Z-5000.

The speciation studies of selected metals in the soil matrix were carried out by adopting the sequential extraction procedure as recommended by Community Bureau of References [15]. The procedure comprised of extracting exchangeable, reducible, oxidizable, and residual fractions by using glacial acetic acid, hydroxyl ammonium chloride, $\mathrm{H}_{2} \mathrm{O}_{2}$ ammonium acetate, and nitric acid, respectively. After each extraction, the contents were centrifuged and subsequently filtered. All the four fractions obtained were analyzed for the estimation of selected metals, that is, $\mathrm{Co}, \mathrm{Fe}, \mathrm{Cd}, \mathrm{Ni}, \mathrm{Pb}$, and Cr by FAAS.

For the determination of trace metals in the rice grains and plant samples, wet acid digestion method was used whereby one gram portion of sample was digested with $\mathrm{HClO}_{3}$ and conc. $\mathrm{HNO}_{3}$ in the presence of traces of $\mathrm{H}_{2} \mathrm{SO}_{4}$. The contents were cooled to room temperature and diluted with doubly distilled water. For Fe and Mn determination, the contents were boiled for few minutes before filtering [14]. All the analyses were performed in triplicate and the corresponding result matched within $0.05 \%$.

2.5. Statistical Analysis of Data. In order to develop the better understanding of the obtained data set on various physicochemical parameters of soil and various metals present in the soil, plants, and grains samples, the univariant and multivariant statistical analyses were performed. They involved the extraction of basic statistical parameters like mean, standard deviation, skewness, and kurtosis essential to determine the spread and distribution of measured data. Correlation coefficient analysis was carried out to establish the correlation pattern of various metal pairs in the same media and also in different media like soil, plant, and grain samples. The multivariate statistical analysis in terms of principal component analysis and cluster analysis were performed by using statistica software [16] to get a better understanding of sources of various metals in the soil, plant, and grain samples [17].

The mobility index values of the soil samples were determined by using the formula provided in literature [18]. A high mobility index of a metal was indicative of its bioavailable and mobile nature [19].

\section{Results and Discussion}

3.1. Physicochemical Parameters. The physicochemical parameters of thirty-five soil samples collected from different paddy fields of Shakargarh, Pakistan are provided in Table 1. The $\mathrm{pH}$ of collected samples was found to be alkaline with small variations. This alkaline $\mathrm{pH}$ may decrease the metal mobility by the formation of precipitates, by increasing the number of available adsorption sites and decreasing the competition of $\mathrm{H}^{+}$for adsorption, and also by increasing the metal stability with humic substances [20]. 
TABLE 1: Descriptive statistics for physico-chemical parameters of soil samples $(n=35)$.

\begin{tabular}{|c|c|c|c|c|c|c|}
\hline & Moisture content (\%) & $\mathrm{pH}$ & Conductivity $(\mu \mathrm{S} / \mathrm{cm})$ & $\mathrm{Cl}^{-}(\mathrm{mg} / \mathrm{kg})$ & $\mathrm{NO}_{3}{ }^{-}(\mathrm{mg} / \mathrm{kg})$ & $\mathrm{SO}_{4}{ }^{2-}(\mathrm{mg} / \mathrm{kg})$ \\
\hline Minimum & 8.000 & 8.1 & 778.0 & 2120 & 1834 & 8200 \\
\hline Maximum & 17.00 & 8.4 & 1090 & $6.24 \times 10^{4}$ & $1.440 \times 10^{5}$ & $2.30 \times 10^{4}$ \\
\hline Mean & 11.79 & 8.2 & 975.4 & 9828 & $2.43 \times 10^{4}$ & $1.401 \times 10^{4}$ \\
\hline Median & 12.00 & 8.2 & 1006 & 3160 & $1.485 \times 10^{4}$ & $1.38 \times 10^{4}$ \\
\hline S D & 2.467 & 0.081 & 90.23 & $1.77 \times 10^{4}$ & $3.389 \times 10^{4}$ & 4819 \\
\hline S.E & 0.504 & 0.017 & 18.41 & 3629 & 6917.961 & 983.7 \\
\hline Kurtosis & -0.623 & 0.070 & -0.022 & 4.597 & 9.297 & -1.121 \\
\hline Skewness & 0.546 & 0.975 & -1.121 & 2.465 & 3.191 & 0.374 \\
\hline Variance & 6.085 & 0.007 & 8141 & $3.16 \times 10^{8}$ & $1.14 \times 10^{9}$ & $2.32 \times 10^{7}$ \\
\hline
\end{tabular}

TABLE 2: Descriptive statistics for metal levels $(\mathrm{mg} / \mathrm{kg})$ in soil, plants, and grains $(n=35)$.

\begin{tabular}{lcccccc}
\hline & $\mathrm{Fe}$ & $\mathrm{Co}$ & $\mathrm{Ni}$ & $\mathrm{Cd}$ & $\mathrm{Pb}$ & $\mathrm{Cr}$ \\
\hline Soil & & & & & & \\
Min. & 1823 & 13.76 & 60.02 & 1.025 & 113.8 & 13.76 \\
Max. & 7498 & 2898 & 99.67 & 78.90 & 2967 & 89.76 \\
Mean & 4074 & 747.2 & 85.84 & 35.02 & 1065 & 37.80 \\
Median & 3455 & 90.22 & 90.68 & 30.70 & 725.5 & 25.51 \\
S D & 2249 & 1180 & 13.61 & 33.95 & 1092 & 27.73 \\
S.E & 459.1 & 240.9 & 2.779 & 6.93 & 222.9 & 5.662 \\
Kurtosis & -1.263 & -0.497 & -0.674 & -2.107 & -1.115 & -0.600 \\
Skewness & 0.591 & 1.240 & -0.936 & 0.054 & 0.656 & 1.115 \\
\hline Plant & & & & & & \\
Min. & 639.3 & 61.97 & 49.11 & 0.040 & 31.34 & 4.280 \\
Max. & 1624 & 80.19 & 64.06 & 2.060 & 67.53 & 15.54 \\
Mean & 1256 & 71.58 & 54.50 & 0.849 & 48.81 & 9.173 \\
Median & 1382 & 72.08 & 52.41 & 0.648 & 48.19 & 8.435 \\
S D & 427.1 & 9.975 & 7.094 & 0.990 & 20.20 & 5.776 \\
S.E & 213.6 & 4.988 & 3.547 & 0.495 & 10.10 & 2.888 \\
Kurtosis & 2.922 & -5.800 & -0.284 & -2.967 & -5.925 & -4.738 \\
Skewness & -1.557 & -0.035 & 1.050 & 0.540 & 0.013 & 0.221 \\
\hline Grain & & & & & & \\
Min. & 243.9 & 40.49 & 38.59 & 0.220 & 38.63 & 4.653 \\
Max. & 1019 & 62.03 & 52.59 & 1.642 & 55.88 & 12.21 \\
Mean & 536.1 & 49.89 & 46.34 & 0.859 & 45.75 & 6.988 \\
Median & 440.8 & 48.51 & 47.09 & 0.788 & 44.25 & 5.544 \\
S D & 335.2 & 8.959 & 6.420 & 0.741 & 8.22 & 3.507 \\
S.E & 167.6 & 4.479 & 3.210 & 0.371 & 4.112 & 1.754 \\
Kurtosis & 2.845 & 1.789 & -2.728 & -5.202 & -2.762 & 3.736 \\
Skewness & 1.522 & 0.882 & -0.424 & 0.139 & 0.561 & 1.911 \\
\hline & & & & & &
\end{tabular}

The high moisture contents were noted for these soil samples that are characteristic of loamy textured soil.

The mean conductivity of the samples was found to be $975.4 \mu \mathrm{Scm}^{-1}$. The chloride, nitrate, and sulphate levels exhibited the order $\mathrm{NO}_{3}{ }^{-}>\mathrm{SO}_{4}{ }^{2-}>\mathrm{Cl}^{-}$with their mean concentrations standing at 24.30, 14.01, and $9.828 \mathrm{~g} / \mathrm{kg}$, respectively. Sources of these enhanced levels were traced in agronomic activities such as use of natural and synthetic fertilizers, herbicides, and pesticides used to improve the

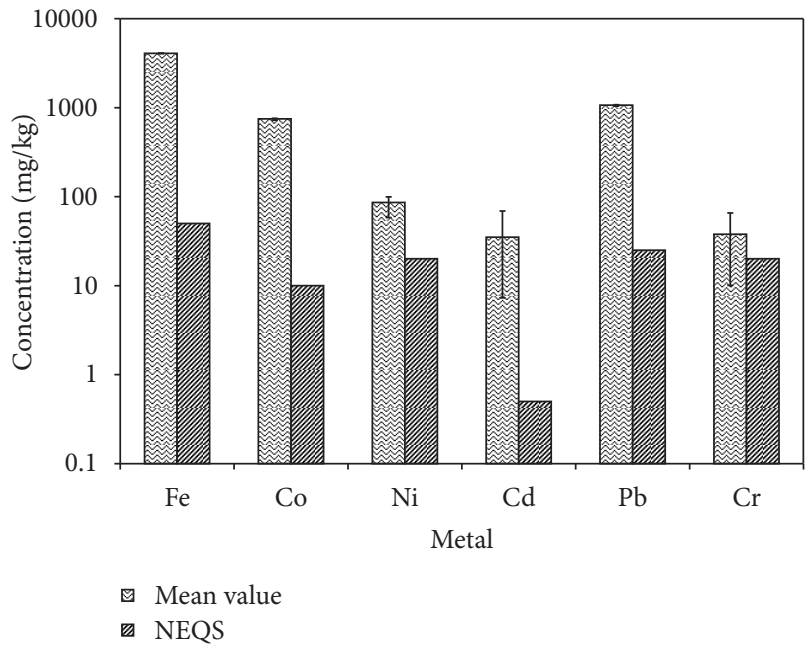

Figure 1: Comparison of mean metal levels in soil ( \pm S.D.) with NEQS.

crop yields. Parental soil quality is another factor that may contribute to the enhanced levels of these anions.

3.2. Metal Levels in the Soil, Plants, and Grain Samples. The total metal contents of soil, plant, and grain samples are presented in Table 2. In the soil samples, Fe was found to be present at the highest mean concentration of $4074 \mathrm{mg} / \mathrm{kg}$ ranging from 1823 to $7498 \mathrm{mg} / \mathrm{kg}$. It was followed by $\mathrm{Pb}$ standing at $1065 \mathrm{mg} / \mathrm{kg}$ with an observed standard deviation of 1092. The order for mean levels of the rest of the metals was $\mathrm{Co}>\mathrm{Ni}>\mathrm{Cr}>\mathrm{Cd}$ with their respective levels being 747.2 > $85.84>37.80>35.02 \mathrm{mg} / \mathrm{kg}$. The large differences observed between mean and median values evidenced nonnormal distribution of the data. Moreover, all the metals exhibited the levels far more exceeding the National Environmental Quality Standards as depicted in Figure 1 [21]. The data set obtained for metals presented an order quite similar to those observed in previous studies $[2,22]$. Although Fe concentration levels are high in the studied soil samples as compared to other metals, these levels are lower than the maximum values established by the European and Spanish legislation for rice-forming soils [23]. 
The addition of fertilizers/micronutrients to the agricultural soils may result in enhanced Fe and Mn levels [24]. These Fe rich soils, under aerobic conditions may act as As accumulators $[25,26]$, which is found in the form of arsenate bound to clay particles. A good correlation, therefore, has been reported between extractable Fe, Mn, and As [27, 28], which may lead to high plant exposure to these metals and thus risk of plant uptake with consequent contamination of whole food chain [29]. Rice has been found to be most efficient at accumulating As into grains than other plants but if rice is grown under aerobic conditions, the extent of bioaccumulation of As and other metals may be reduced [30]. Further, reducing conditions and presence of organic matter may promote As mobilization to groundwaters through ion exchange mechanisms with phosphorous derived from fertilizers [31-33] thereby making it unfit for any viable human use.

In order to study the influence of enhanced metal levels in the soil on the plants and human populations, the metal content of rice plants and grains raised in these soils was also determined and incorporated in Table 2 in the form of descriptive statistics. The data evidenced Fe to be present at the highest mean level of $1256 \mathrm{mg} / \mathrm{kg}$ in rice plants ranging from 639.3 to $1624 \mathrm{mg} / \mathrm{kg}$. It was followed by Co being present at mean level of $71.58 \mathrm{mg} / \mathrm{kg}$. $\mathrm{Ni}$ and $\mathrm{Pb}$ were found to be present at mean concentrations of 54.50 and $48.81 \mathrm{mg} / \mathrm{kg}$, respectively. $\mathrm{Cr}$ was present at quite smaller levels than $\mathrm{Co}$ and Ni but still at appreciable levels of $9.173 \mathrm{mg} / \mathrm{kg}$. Cd was the metal that was present at the least mean concentration of $0.849 \mathrm{mg} / \mathrm{kg}$. Thus, the overall order of mean concentrations of metals in rice plants was found to be $\mathrm{Fe}>\mathrm{Co}>\mathrm{Ni}>\mathrm{Pb}>$ $\mathrm{Cr}>\mathrm{Cd}$.

The corresponding data set for rice grains obtained from these rice plants also presented $\mathrm{Fe}$ to be present at the highest mean concentration of $536.1 \mathrm{mg} / \mathrm{kg}$. Co was the metal that secured the second highest concentration of $62.03 \mathrm{mg} / \mathrm{kg}$ against the mean concentration of $49.89 \mathrm{mg} / \mathrm{kg}$. $\mathrm{Pb}$ was present at a mean concentration of $45.75 \mathrm{mg} / \mathrm{kg}$, far exceeding the permissible limits in rice grains in China and Australia, that is, 0.3 to $5.2 \mathrm{mg} / \mathrm{kg}$ [34-36]. Cd was found at sub-ppm levels and was well within the safety limits that were set to range from 0.02 to $1 \mathrm{mg} / \mathrm{kg}$ in China, Australia, and Japan for rice grains [26]. The order of mean metal levels for the present study was found to be $\mathrm{Fe}>\mathrm{Co}>\mathrm{Ni}>\mathrm{Pb}>\mathrm{Cr}>$ $\mathrm{Cd}$. Thus, the studied rice grains exhibited mean $\mathrm{Pb}$ levels far exceeding the safe limits. The data set obtained for grains also presented mean metal order quite comparable to that found in plants.

The orders of various metals observed in three media were quite comparable with few exceptions, that is, $\mathrm{Pb}$ secured the second highest position in soil while in the plant and grain samples it was present at the fourth position. The highest levels of Fe in the three media depicted their similar origin. The different orders of metals in these media may be explained on the basis of differences in nature of these metals and their bioavailability in the soil.

$\mathrm{Ni}, \mathrm{Co}$, and $\mathrm{Cr}$ concentrations were also comparable in both soil and plant samples with small variations as the bioavailability of metals depends upon the nature of the metal and the properties of soil. It is observed that metals from anthropogenic sources tend to be more mobile than pedogenic or lithogenic ones.

High concentration of metals in the soil does not necessarily imply their availability to plants. In the solid phase, the metals are distributed among the various soil components thereby producing various physicochemical forms that determine metal mobility [19]. Thus, in order to better assess the bioavailability of metals and their chemical association with the soil components metal fractionation behavior was studied by using the fractionation scheme proposed by community bureau of references.

The results of the fractionation analysis of the metals in the soil are presented in Table 3, where the mean values for each fraction are reported. The distribution of the metals in various operationally defined fractions evidenced that Fe was mostly found to be associated with oxidizable fraction $(1743 \mathrm{mg} / \mathrm{kg})$. The reducible fraction of this metal was also present at an appreciable concentration of $1590 \mathrm{mg} / \mathrm{kg}$. The least amount was found to be associated with acid soluble fraction, that is, $80.77 \mathrm{mg} / \mathrm{kg}$. For Co most of the metal was found to be associated with oxidizable fraction $(372.5 \mathrm{mg} / \mathrm{kg})$. The overall order of mean levels of all the fractions was oxidizable $>$ residual $>$ reducible $>$ acid soluble. $\mathrm{Ni}$ being present at a total concentration of $85.84 \mathrm{mg} / \mathrm{kg}$ was mostly associated with oxidizable and residual fractions with mean concentration of 24.10 and $19.61 \mathrm{mg} / \mathrm{kg}$, respectively. Reducible fraction of this metal was present at mean level of $16.67 \mathrm{mg} / \mathrm{kg}$, while the acid soluble fraction was found to be present at mean levels of $14.86 \mathrm{mg} / \mathrm{kg}$. The mobility index of this metal was found to be 0.183 .

$\mathrm{Cd}$, another heavy metal, was present at a total mean concentration of $35.02 \mathrm{mg} / \mathrm{kg}$. The highest concentration of this metal was found to be associated with oxidizable fraction, that is, $10.80 \mathrm{mg} / \mathrm{kg}$. The acid soluble and reducible fractions were present at comparable levels of 9.012 and $9.011 \mathrm{mg} / \mathrm{kg}$, respectively. Least concentration of the metal was found to be associated with residual fraction. The percent recovery of the metal was found to be 85.40 with a mobility index of 0.219 .

$\mathrm{Pb}$ being present at a total concentration of $1065 \mathrm{mg} / \mathrm{kg}$ exhibited a total recovery of $99.60 \%$ during distribution among the four fractions. Its highest concentration was present in acid soluble fraction. Oxidizable fraction exhibited the second highest concentration of $377.4 \mathrm{mg} / \mathrm{kg}$, while reducible fraction was present at about $216 \mathrm{mg} / \mathrm{kg}$ concentrations. The least concentration of this metal was found to be associated with residual fraction. The mobility index of the metal was found to be 0.330 . Cr, one of the most hazardous metals, was found to be associated mostly with oxidizable fraction $(16.06 \mathrm{mg} / \mathrm{kg})$. The order of the rest of the fractions was found to be residual $>$ acid soluble $>$ reducible. The percentage recovery of this metal was found to be $96.52 \%$ with a mobility index of 0.183 .

The mobility of an element is its capacity to pass into soil compartments where it is less energetically retained [37]. The extractable content of a heavy metal is an indicator of the quantity of metals available to plants. The proportion of this fraction relative to the total amount of the metal is also an indicator of its comparative mobility [4]. The comparison of 
TABLE 3: Fractionation studies of metals in soil of rice fields, $n=35$ (mean \pm SD).

\begin{tabular}{lcccccc}
\hline & ${ }^{\mathrm{a}} \mathrm{F} 1$ & ${ }^{\mathrm{b}} \mathrm{F} 2$ & ${ }^{\mathrm{c}} \mathrm{F} 3$ & ${ }^{\mathrm{d}} \mathrm{F} 4$ & Mobility index & Total metal \\
\hline $\mathrm{Fe}$ & $80.77 \pm 59.72$ & $1590 \pm 376.9$ & $1743.2 \pm 2272$ & $198.40 \pm 155.2$ & 0.037 & $4073.5 \pm 2249$ \\
$\mathrm{Co}$ & $53.10 \pm 60.60$ & $70.87 \pm 90.65$ & $372.5 \pm 618.4$ & $117.50 \pm 171.8$ & 0.185 & $747.2 \pm 1179$ \\
$\mathrm{Cr}$ & $5.552 \pm 2.174$ & $5.215 \pm 1.759$ & $16.06 \pm 19.51$ & $6.885 \pm 5.593$ & 0.183 & $37.8 \pm 27.57$ \\
$\mathrm{Ni}$ & $14.86 \pm 9.416$ & $16.67 \pm 9.173$ & $24.10 \pm 11.16$ & $19.61 \pm 14.06$ & 0.272 & $85.84 \pm 13.28$ \\
$\mathrm{~Pb}$ & $391.2 \pm 477.3$ & $216.1 \pm 345.6$ & $377.4 \pm 381.8$ & $18.26 \pm 9.693$ & 0.330 & $1065 \pm 1081$ \\
$\mathrm{Cd}$ & $9.012 \pm 8.712$ & $9.011 \pm 8.794$ & $10.80 \pm 10.44$ & $2.433 \pm 2.046$ & 0.219 & $35.02 \pm 33.78$ \\
\hline
\end{tabular}

${ }^{\mathrm{a}}$ Acid soluble. ${ }^{\mathrm{b}}$ Reducible. ${ }^{\mathrm{c}}$ Oxidizable. ${ }^{\mathrm{d}}$ Residual.

TABLE 4: Correlation coefficient matrix for various parameters in respective soil, plants, and grain samples $(n=35)$.

\begin{tabular}{|c|c|c|c|c|c|c|}
\hline & $\mathrm{Fe}$ & Co & $\mathrm{Ni}$ & $\mathrm{Cd}$ & $\mathrm{Pb}$ & $\mathrm{Cr}$ \\
\hline Moist. Content (\%) & 0.374 & -0.392 & -0.088 & -0.159 & -0.296 & -0.325 \\
\hline $\mathrm{pH}$ & 0.018 & -0.495 & -0.097 & -0.259 & -0.41 & -0.483 \\
\hline $\mathrm{EC}(\mu \mathrm{S} / \mathrm{cm})$ & 0.008 & 0.366 & -0.565 & 0.693 & 0.604 & 0.464 \\
\hline $\mathrm{Cl}^{-}(\mathrm{mg} / \mathrm{kg})$ & -0.39 & -0.221 & -0.713 & 0.318 & 0.106 & -0.112 \\
\hline $\mathrm{NO}_{3}{ }^{-}(\mathrm{mg} / \mathrm{kg})$ & -0.071 & 0.217 & -0.163 & 0.332 & 0.35 & 0.246 \\
\hline $\mathrm{SO}_{4}{ }^{2-}(\mathrm{mg} / \mathrm{kg})$ & -0.187 & 0.696 & 0.336 & 0.235 & 0.511 & 0.617 \\
\hline \multicolumn{7}{|l|}{ Soil } \\
\hline $\mathrm{Fe}$ & 1.000 & & & & & \\
\hline Co & 0.127 & 1.000 & & & & \\
\hline $\mathrm{Ni}$ & 0.554 & 0.085 & 1.000 & & & \\
\hline $\mathrm{Cd}$ & -0.352 & 0.634 & -0.686 & 1.000 & & \\
\hline $\mathrm{Pb}$ & -0.155 & 0.869 & -0.372 & 0.912 & 1.000 & \\
\hline $\mathrm{Cr}$ & 0.050 & 0.978 & -0.080 & 0.758 & 0.930 & 1.000 \\
\hline \multicolumn{7}{|l|}{ Plant } \\
\hline $\mathrm{Fe}$ & 1.000 & & & & & \\
\hline Co & 0.260 & 1.000 & & & & \\
\hline $\mathrm{Ni}$ & 0.155 & -0.914 & 1.000 & & & \\
\hline $\mathrm{Cd}$ & -0.632 & -0.913 & 0.668 & 1.000 & & \\
\hline $\mathrm{Pb}$ & -0.385 & -0.991 & 0.852 & 0.959 & 1.000 & \\
\hline $\mathrm{Cr}$ & -0.135 & -0.992 & 0.958 & 0.853 & 0.966 & 1.000 \\
\hline \multicolumn{7}{|l|}{ Grains } \\
\hline $\mathrm{Fe}$ & 1.000 & & & & & \\
\hline $\mathrm{Co}$ & 0.183 & 1.000 & & & & \\
\hline $\mathrm{Ni}$ & -0.445 & -0.930 & 1.000 & & & \\
\hline $\mathrm{Cd}$ & -0.314 & 0.743 & -0.446 & 1.000 & & \\
\hline $\mathrm{Pb}$ & -0.593 & -0.563 & 0.820 & 0.132 & 1.000 & \\
\hline $\mathrm{Cr}$ & -0.322 & -0.164 & 0.459 & 0.474 & 0.860 & 1.000 \\
\hline
\end{tabular}

$r$-values are significant at \pm 0.282 at $P=0.05$.

mobility index values evidenced $\mathrm{Pb}$ to be highly mobile and thus bioavailable. Thus, its higher concentration may leach to water and enter the plant bodies. This fact justified the higher concentration of $\mathrm{Pb}$ in plants as well as grain samples. Next higher mobility index value was observed for $\mathrm{Ni}$, which was also concentrated into the plant bodies and grain samples. The rest of the metals followed the order of mobility indices as follows: $\mathrm{Cd}>\mathrm{Co}>\mathrm{Cr}>\mathrm{Fe}$.

3.3. Correlation Coefficient Matrix. The deficiency or excess of micronutrients in soil is directly associated with the plant uptake, which is indirectly associated with soil physicochemical characteristics and plant species. The physicochemical characteristics of soil are known to control the fate of the metals and largely influence the plant-soil interaction through rhizospheric processes.

The correlation coefficient matrix for various metals and physicochemical parameters of soil is presented in Table 4 . The $\mathrm{pH}$ of these soil samples was found to be significantly negatively correlated with $\mathrm{Co}, \mathrm{Pb}$, and $\mathrm{Cr}$ with $r$-values of $0.495,0.410$, and 0.483 , respectively. Chloride was also found to be significantly negatively correlated with Fe and $\mathrm{Ni}$. Sulphate on the other hand was found to be significantly 
TABLE 5: Correlation coefficient matrix for metal levels in different media $(n=35)$.

\begin{tabular}{lcccccc}
\hline & $\mathrm{Fe}(\mathrm{s})$ & $\mathrm{Co}(\mathrm{s})$ & $\mathrm{Ni}(\mathrm{s})$ & $\mathrm{Cd}(\mathrm{s})$ & $\mathrm{Pb}(\mathrm{s})$ & $\mathrm{Cr}(\mathrm{s})$ \\
\hline $\mathrm{Fe}(\mathrm{p})$ & 0.406 & -0.240 & 0.342 & -0.177 & 0.358 & 0.301 \\
$\mathrm{Co}(\mathrm{p})$ & -0.182 & 0.488 & -0.597 & -0.498 & -0.602 & -0.437 \\
$\mathrm{Ni}(\mathrm{p})$ & 0.535 & -0.507 & 0.557 & 0.412 & 0.487 & 0.604 \\
$\mathrm{Cd}(\mathrm{p})$ & -0.031 & -0.128 & 0.063 & 0.180 & 0.080 & -0.149 \\
$\mathrm{~Pb}(\mathrm{p})$ & 0.672 & -0.799 & 0.815 & 0.696 & 0.604 & 0.889 \\
$\mathrm{Cr}(\mathrm{p})$ & 0.783 & -0.809 & 0.792 & 0.653 & 0.646 & 0.904 \\
\hline & $\mathrm{Fe}(\mathrm{s})$ & $\mathrm{Co}(\mathrm{s})$ & $\mathrm{Ni}(\mathrm{s})$ & $\mathrm{Cd}(\mathrm{s})$ & $\mathrm{Pb}(\mathrm{s})$ & $\mathrm{Cr}(\mathrm{s})$ \\
\hline $\mathrm{Fe}(\mathrm{g})$ & 0.400 & -0.209 & 0.048 & 0.565 & -0.332 & 0.165 \\
$\mathrm{Co}(\mathrm{g})$ & -0.535 & 0.566 & -0.599 & -0.195 & -0.604 & -0.378 \\
$\mathrm{Ni}(\mathrm{g})$ & 0.270 & -0.222 & 0.348 & 0.256 & 0.596 & 0.444 \\
$\mathrm{Cd}(\mathrm{g})$ & -0.457 & 0.481 & -0.338 & -0.429 & -0.427 & -0.323 \\
$\mathrm{~Pb}(\mathrm{~g})$ & 0.312 & -0.407 & 0.631 & 0.059 & 0.672 & 0.463 \\
$\mathrm{Cr}(\mathrm{g})$ & -0.259 & 0.082 & 0.166 & 0.078 & 0.130 & 0.129 \\
\hline & $\mathrm{Fe}(\mathrm{g})$ & $\mathrm{Co}(\mathrm{g})$ & $\mathrm{Ni}(\mathrm{g})$ & $\mathrm{Cd}(\mathrm{g})$ & $\mathrm{Pb}(\mathrm{g})$ & $\mathrm{Cr}(\mathrm{g})$ \\
\hline $\mathrm{Fe}(\mathrm{p})$ & -0.066 & 0.076 & 0.237 & 0.221 & 0.161 & 0.013 \\
$\mathrm{Co}(\mathrm{p})$ & -0.290 & 0.072 & -0.353 & 0.114 & -0.318 & -0.500 \\
$\mathrm{Ni}(\mathrm{p})$ & 0.033 & -0.030 & 0.415 & 0.170 & 0.250 & 0.242 \\
$\mathrm{Cd}(\mathrm{p})$ & -0.211 & 0.399 & -0.517 & -0.146 & -0.346 & -0.398 \\
$\mathrm{~Pb}(\mathrm{p})$ & 0.294 & 0.016 & 0.212 & 0.104 & 0.325 & 0.409 \\
$\mathrm{Cr}(\mathrm{p})$ & -0.252 & 0.109 & -0.428 & 0.094 & 0.049 & -0.303 \\
\hline $\mathrm{r}-\mathrm{V}$ & & & & &
\end{tabular}

$r$-values are significant at \pm 0.282 at $P=0.05$ level; s: soil, p: rice plant, and g: rice grain.

positively correlated with $\mathrm{Pb}, \mathrm{Co}$, and $\mathrm{Cr}$ with $r$-values of $0.511,0.696$, and 0.617 , respectively.

The data presented in Table 4 evidenced a number of strong correlations among various metal pairs in different media. In case of soil, a strong positive correlation was observed between $\mathrm{Cd}$ and $\mathrm{Pb}$ with an $r$-value of 0.912 , and $\mathrm{Pb}$ and $\mathrm{Cr}$ with $r$-value of 0.930 . Cr was also strongly positively correlated with $\mathrm{Co}(r$-value 0.978$)$. Similarly, $\mathrm{Pb}$ was strongly positively correlated with Co (0.869). The strong positive correlations evidenced the similar origin of these metal pairs. Three of the studied metal pairs in the soil were found to be significantly negatively correlated, that is, $\mathrm{Cd}-\mathrm{Fe}, \mathrm{Ni}-\mathrm{Cd}$, and $\mathrm{Pb}-\mathrm{Ni}$ evidencing the increase in the concentration of one metal with the decrease in the concentration of another.

In plant samples, Co was found to be significantly negatively correlated with almost all the metals with the exception of Fe. Cd-Fe pair in plant samples was found to be negatively correlated, and $\mathrm{Cd}$ was positively correlated with $\mathrm{Pb}$ and $\mathrm{Cr}$ similar to soil. In case of grain samples, the strongest negative correlation was observed between Co-Ni pair with an $r$-value of 0.930 . Fe was also found to be negatively correlated with $\mathrm{Ni}$ and $\mathrm{Pb}$. Similarly, negative correlation was observed between $\mathrm{Co}-\mathrm{Pb}$ pair. The strongest positive correlation was found in $\mathrm{Pb}-\mathrm{Cr}$ pair, a situation quite similar to one encountered in plant and soil samples, evidencing their common origin in the three media. Ni-Cd pair in rice grains was significantly negatively correlated similar to soil. $\mathrm{Cu}-\mathrm{Ni}$ and $\mathrm{Co}-\mathrm{Pb}$ pairs were found to be significantly negatively correlated in plant and rice grain samples while they exhibited a significantly positive correlation in plant matrix, the reason may be traced in the phytoavailability of metals.

The correlation coefficient matrix for the metals in different media, that is, soil, plant, and grains is presented in Table 5. In case of soil versus plant metal correlation, the strongest positive correlation was observed between $\mathrm{Cr}$ contents in the two media, evidencing that the source of enhanced $\mathrm{Cr}$ levels in the plants originates from their enhanced levels in the soil. It was also supported by the high percentage of oxidizable fraction of $\mathrm{Cr}$ present in the soil. No such correlation was observed between $\mathrm{Cr}$ of soil and $\mathrm{Cr}$ of grains. It was indicative of the fact that although soil enhanced levels lead to absorption of $\mathrm{Cr}$ from soil, this excessive $\mathrm{Cr}$ was not translocated to the grains. It was also evidenced by a negative correlation between $\mathrm{Cr}$ (plants) and $\mathrm{Cr}$ (grains).

$\mathrm{Pb}$ of the soil was also significantly positively correlated with $\mathrm{Pb}$ of plants. Similarly $\mathrm{Pb}$ of soil was also significantly positively correlated with $\mathrm{Pb}$ contents of rice grains. As the grains constitute a direct edible part of plants, their accumulation of $\mathrm{Pb}$ is quite hazardous and may lead to various health hazards among the people consuming it. Similarly, $\mathrm{Ni}, \mathrm{Co}$, and Fe of soil were also found to be strongly positively associated with these metals in plant samples, but in case of rice grains only $\mathrm{Ni}$ was found to be significantly positively correlated. This matrix evidenced that enhanced levels of almost all the studied metals in the soil lead to an enhanced uptake by the arable parts of rice plants but these metals with the exception of $\mathrm{Pb}$ were not translocated to the grains, thus not posing any threat to human beings directly but indirectly they may constitute hazards because these arable parts may be used as food by the animals that constitute food for humans.

\subsection{Source Apportionment Studies}

3.4.1. Principle Component Analysis (PCA). The sources of various metals in soil, plants, and grain samples were determined in terms of varimax normalized factor loading (Table 6). Only two rotated factors were obtained for the total metal contents of various metals present in thirtyfive soil samples collected from different rice fields with a cumulative eigenvalue of $88.53 \%$. The first factor received major contribution from $\mathrm{Co}, \mathrm{Cd}, \mathrm{Pb}$, and $\mathrm{Cr}$, while the second factor being associated with an eigen value of 1.746 received major loadings from $\mathrm{Fe}$ and Ni. It is noteworthy that the metals arising from nitrate fertilizers, that is, $\mathrm{Cd}$ and $\mathrm{Co}$, are grouped together in a single factor depicting their similar source.

The most significant sources of Fe in the soil are various fertilizers that are added to the soil to replenish various deficiency symptoms. It may also have geologic origins. It has been found that soils rich in Fe and $\mathrm{Mn}$ are also having enhanced As levels [38]. The sources of $\mathrm{Pb}$ in soil are traced in various fungicide and pesticide sprays that are used at various stages of crop production, containing $\mathrm{Pb}$ as an impurity [39]. It is known that phosphatic fertilizers are manufactured by using the phosphate ore, which is contaminated with different metals such as Pd, Cr, and Fe. These metal contaminants 
TABLE 6: Varimax normalized factor loadings for metals in soil, plant, and grain samples.

\begin{tabular}{|c|c|c|c|c|c|c|}
\hline \multirow{2}{*}{ Factor } & \multicolumn{2}{|c|}{ Soil } & \multicolumn{2}{|c|}{ Plant } & \multicolumn{2}{|c|}{ Grain } \\
\hline & 1 & 2 & 1 & 2 & 1 & 2 \\
\hline $\mathrm{Fe}$ & 0.069 & 0.834 & 0.413 & 0.808 & -0.7 & -0.070 \\
\hline Co & 0.912 & 0.18 & -0.555 & 0.322 & -0.086 & -0.809 \\
\hline $\mathrm{Ni}$ & -0.136 & 0.912 & 0.813 & -0.042 & 0.266 & 0.809 \\
\hline $\mathrm{Cd}$ & 0.787 & -0.587 & 0.256 & -0.86 & 0.628 & -0.657 \\
\hline $\mathrm{Pb}$ & 0.949 & -0.275 & 0.895 & 0.131 & 0.701 & 0.528 \\
\hline $\mathrm{Cr}$ & 0.977 & 0.016 & 0.927 & 0.099 & 0.807 & 0.110 \\
\hline Eigenvalue & 3.566 & 1.746 & 2.875 & 1.516 & 2.453 & 1.689 \\
\hline$\%$ Total variance & 59.43 & 29.11 & 47.92 & 25.27 & 40.89 & 28.15 \\
\hline Cumulative eigenvalue & 3.566 & 5.312 & 2.875 & 4.391 & 2.453 & 4.142 \\
\hline Cumulative $\%$ & 59.43 & 88.53 & 47.92 & 73.19 & 40.89 & 69.04 \\
\hline
\end{tabular}

also become a part of fertilizer and on application to soil lead to hazardous effects [40]. This $\mathrm{Pb}$ contamination of paddy soils may change the soil microorganisms and soil enzymatic activities and deteriorate the soil fertility, which may directly affect the rice physiological indices and results in rice yield decline and quality deterioration. Ultimately, $\mathrm{Pb}$ accumulates in human body through food chain and thus endangers human health [34].

These fertilizers contain not only higher amounts of $\mathrm{Fe}$, $\mathrm{Co}$, and $\mathrm{Pb}$ but also traces of $\mathrm{Cd}$ and $\mathrm{Ni}$ as impurities that constitute the sources of their enhanced levels in the soil. The levels of heavy metals determined by several authors in phosphate fertilizers were $0.1-170 \mathrm{mg} \mathrm{kg}^{-1} \mathrm{Cd}, 1-12 \mathrm{mg} \mathrm{kg}^{-1}$ Co, $7-38 \mathrm{mg} \mathrm{kg}^{-1} \mathrm{Ni}, 7-225 \mathrm{mg} \mathrm{kg}^{-1} \mathrm{~Pb}$ while in the nitrate fertilizers they were $0.05-8.5 \mathrm{mg} \mathrm{kg}^{-1} \mathrm{Cd}$ and $5.4-12 \mathrm{mg} \mathrm{kg}^{-1}$ Co. Moreover, the heavy metals also form a part of the active compounds of pesticides. Thus repeated and excessive fertilizer and pesticide applications may lead to much enhanced concentrations of heavy metals in the soil [22].

Sewage sludge is commonly used in agriculture as soil conditioner/fertilizer due to easy availability and low costs [41]. But it may also contain substantial amounts of toxic metals such as $\mathrm{Zn}, \mathrm{Cu}, \mathrm{Cr}, \mathrm{Ni}, \mathrm{Cd}$, and $\mathrm{Pb}$ [42-44], which are quite mobile due to the presence of organic matter in sewage sludge [45]. In addition to direct application, municipal sewage sludge disposed of through land filling is also a potential source of spreading toxic metals to nearby lands [46]. Thus, sewage sludge is also a major contributor of metals in agricultural lands and poses serious threats to human health and environment $[47,48]$.

The varimax normalized factor loadings were also recorded for the metal data of rice plant samples to trace the sources of various metals. Similar to the soil samples again, two rotated factors were obtained. The first factor being associated with a cumulative variance of $47.92 \%$ received major contribution from $\mathrm{Ni}, \mathrm{Pb}$, and $\mathrm{Cr}$, thereby depicting similar origin of these metals in the rice plants from agrochemicals that are used simultaneously and contain these metals. The second factor received major contribution from two metals only, that is, $\mathrm{Fe}$ and $\mathrm{Cd}$.

The rice grains are the edible part of the plant used throughout the world, so it is quite imperative to evaluate their quality in terms of total metal content. Thus varimax normalized rotation of metal data of rice grains yielded two rotated factors with cumulative variance of $69.04 \%$. First factor received major loading for $\mathrm{Pb}$ and $\mathrm{Cr}$ similar to plant samples. Fe was another major contributor of this factor. Factor 2 was mainly associated with $\mathrm{Co}$ and $\mathrm{Ni}$ with an eigenvalue of 1.698 .

The food chain (soil-plant-human) pathway is recognized as one of the major pathways for human exposure to soil contamination. However, the ingested dose of heavy metals is not equal to the absorbed pollutant dose in reality, as a fraction of the ingested heavy metals may be excreted, with the remainder accumulated in body tissues where they affect human health [19]. Similarly, only limited quantities of metals are absorbed into the upper parts of the plants, probably because the roots act as a barrier to the translocation of metals within the plant [49]. The phenomenon is thus responsible for different metal levels in different parts of plants.

3.4.2. Cluster Analysis. The clustering behavior of the selected metals in soil, plant, and grain samples was studied by cluster analysis and is depicted in Figure 2. In case of soil samples, the selected metals formed two primary clusters within linkage distance of 0.5 . One of the primary clusters comprised of $\mathrm{Fe}$ and $\mathrm{Ni}$ depicting their similar origin. The second cluster comprised of $\mathrm{Cr}, \mathrm{Pb}, \mathrm{Cd}$, and $\mathrm{Co}$, all linked within linkage distance of 0.2 , evidencing their close association.

In case of plant samples, Fe stood alone depicting its different source. Similar to plant samples $\mathrm{Pb}, \mathrm{Cr}$, and $\mathrm{Ni}$ were found to be associated closely within linkage distance of 0.5 , depicting their common origin in plants and grains. On overall basis, the cluster analysis confirmed the findings of the principle component analysis.

\section{Conclusion}

The present study evidenced enhanced levels of all the studied metals in the paddy soil samples due to abundant and unmanaged use of agrochemicals. The sequential extraction procedure revealed that the oxidizable and reducible phases 


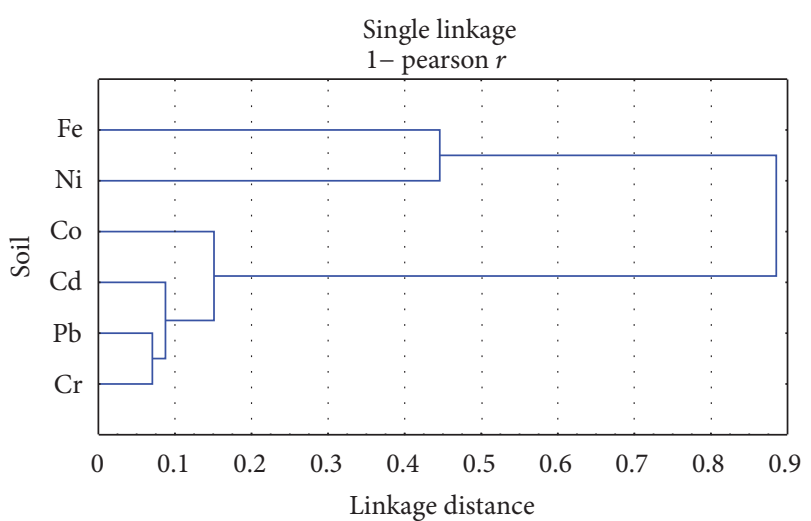

(a)

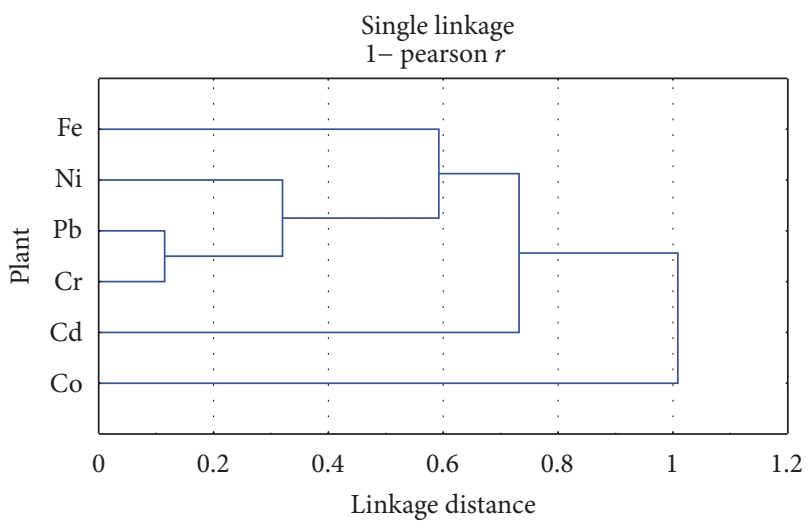

(b)

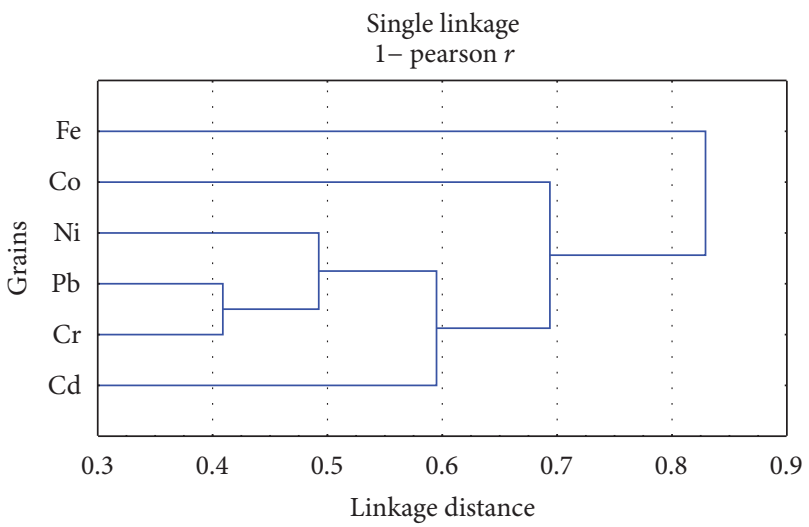

(c)

Figure 2: Cluster analysis of metals in soil, plants, and grains.

of metals like Fe and Ni were predominant and they exhibited reduced mobility index values in the soil samples. $\mathrm{Pb}$ and $\mathrm{Cd}$ possessed high mobility due to their very high extractability in acid soluble fraction. The correlation coefficient matrix evidenced that enhanced metal levels in soil may lead to their accumulation in aerial parts of plants but not in edible parts of plants, that is, grains. A quite hazardous situation was observed where the rice grains in addition to aerial parts of plants also accumulated $\mathrm{Pb}$, which may lead to various health hazards. Despite these hazards, rice plants may act a hyperaccumulators of $\mathrm{Cr}, \mathrm{Ni}, \mathrm{Co}$, and $\mathrm{Fe}$ by accumulating these metals in their aerial parts but not in edible parts. The study also evidenced that there is a dire need to address the problem of agricultural soil pollution and to educate the farmers about the optimum and wise use of agrochemicals.

\section{References}

[1] S. C. Wong, X. D. Li, G. Zhang, S. H. Qi, and Y. S. Min, "Heavy metals in agricultural soils of the Pearl River Delta, South China," Environmental Pollution, vol. 119, no. 1, pp. 33-44, 2002.

[2] S. E. Lorenz, R. E. Hamon, S. P. McGrath, P. E. Holm, and T. H. Christensen, "Applications of fertilizer cations affect cadmium and zinc concentrations in soil solutions and uptake by plants," European Journal of Soil Science, vol. 45, no. 2, pp. 159-165, 1994.

[3] K. C. Sekhar, K. R. Supriya, C. T. Kamala, N. S. Chary, T. N. Rao, and Y. Anjaneyulu, "Speciation, accumulation of heavy metals in vegetation grown on sludge amended soils and their transfer to human food chain-a case study," Toxicological and Environmental Chemistry, vol. 82, no. 1-2, pp. 33-43, 2001.

[4] Z. L. He, M. Zhang, X. E. Yang, and P. J. Stoffella, "Release behavior of copper and zinc from sandy soils," Soil Science Society of America Journal, vol. 70, no. 5, pp. 1699-1707, 2006.

[5] R. G. McLaren and L. M. Clucas, "Fractionation of copper, nickel, and zinc in metal-spiked sewage sludge," Journal of Environmental Quality, vol. 30, no. 6, pp. 1968-1975, 2001.

[6] A. K. Gupta, S. Sinha, A. Basant, and K. P. Singh, "Multivariate analysis of selected metals in agricultural soil receiving UASB treated tannery effluent at Jajmau, Kanpur (India)," Bulletin of Environmental Contamination and Toxicology, vol. 79, no. 5, pp. 577-582, 2007.

[7] A. Qishlaqi and F. Moore, "Statistical analysis of accumulation and sources of heavy metals occurrence in agricultural soils of Khoshk river banks, Shiraz, Iran," American-Eurasian Journal of Agricultural \& Environmental Sciences, vol. 2, pp. 565-573, 2007.

[8] G. Shen, Y. Lu, M. Wang, and Y. Sun, "Status and fuzzy comprehensive assessment of combined heavy metal and organochlorine pesticide pollution in the Taihu Lake region of China," Journal of Environmental Management, vol. 76, no. 4, pp. 355-362, 2005.

[9] Q. W. Yang, C. Y. Lan, H. B. Wang, P. Zhuang, and W. S. Shu, "Cadmium in soil-rice system and health risk associated with the use of untreated mining wastewater for irrigation in Lechang, China," Agricultural Water Management, vol. 84, no. 1-2, pp. 147-152, 2006.

[10] Q. W. Yang, C. Y. Lan, and W. S. Shu, "Copper and Zinc in a paddy field and their potential ecological impacts affected by wastewater from a lead/zinc mine, P. R. China," Environmental Monitoring and Assessment, vol. 147, no. 1-3, pp. 65-73, 2008.

[11] “International Rice Research Institute Las Banas IRRI," Institute Las Banas, Phillipines, 2005.

[12] N. Prakongkep, A. Suddhiprakarn, I. Kheoruenromne, and R. J. Gilkes, "Micromorphological properties of Thai paddy soils," Kasetsart Journal : Natural Science, vol. 41, no. 5, pp. 42-48, 2007.

[13] M. Zazoli and A. Edris, "Determination and estimation of Cd intake from Tarom rice," Journal of Applied Sciences and Environmental Management, vol. 10, pp. 147-150, 2006. 
[14] M. Radojevic and V. N. Bashkin, Practical Environmental Analysis, Royal Society of Chemistry, Cambridge UK, 1999.

[15] M. Chen, X. M. Li, Q. Yang et al., "Total concentrations and speciation of heavy metals in municipal sludge from Changsha, Zhuzhou and Xiangtan in middle-south region of China," Journal of Hazardous Materials, vol. 160, no. 2-3, pp. 324-329, 2008.

[16] Statsoft inc, "STATISTICA software for windows," Computer Program Manual, Tulsa, Okla, USA, 1999.

[17] S. R. Tariq, M. H. Shah, N. Shaheen, A. Khalique, S. Manzoor, and M. Jaffar, "Multivariate analysis of selected metals in tannery effluents and related soil," Journal of Hazardous Materials, vol. 122, no. 1-2, pp. 17-22, 2005.

[18] C. Kabala and B. R. Singh, "Fractionation and mobility of copper, lead, and zinc in soil profiles in the vicinity of a copper smelter," Journal of Environmental Quality, vol. 30, no. 2, pp. 485-492, 2001.

[19] H. Horiguchi, E. Oguma, S. Sasaki et al., "Dietary exposure to cadmium at close to the current provisional tolerable weekly intake does not affect renal function among female Japanese farmers," Environmental Research, vol. 95, no. 1, pp. 20-31, 2004.

[20] G. Petruzzelli, "Recycling wastes in agriculture: heavy metal bioavailability," Agriculture, Ecosystems and Environment, vol. 27, no. 1-4, pp. 493-503, 1989.

[21] NEQS, "Pakistan environmental protection agency," Government of Pakistan, 1999.

[22] E. Gimeno-García, V. Andreu, and R. Boluda, "Heavy metals incidence in the application of inorganic fertilizers and pesticides to rice farming soils," Environmental Pollution, vol. 92, no. 1, pp. 19-25, 1996.

[23] "Council of the European Communities (CEC)," Directive N 278 of 6/12/1986, Commission of the European Communities, Brussels, Belgium, 1986.

[24] J. Hart, R. Fletcher, C. Landgren, D. Horneck, S. Webster, and M. Bondi, Christmas Tree Nutrient Management Guide For Western Oregon and Washington, EM 8856-E, Oregon State University Extension, 2004.

[25] R. S. Oremland and J. F. Stolz, "The ecology of arsenic," Science, vol. 300, no. 5621, pp. 939-944, 2003.

[26] S. Silver and L. T. Phung, "Genes and enzymes involved in bacterial oxidation and reduction of inorganic arsenic," Applied and Environmental Microbiology, vol. 71, no. 2, pp. 599-608, 2005.

[27] P. M. Fox and H. E. Doner, "Trace element retention and release on minerals and soil in a constructed wetland," Journal of Environmental Quality, vol. 31, no. 1, pp. 331-338, 2002.

[28] P. L. Smedley and D. G. Kinniburgh, "A review of the source, behaviour and distribution of arsenic in natural waters," Applied Geochemistry, vol. 17, no. 5, pp. 517-568, 2002.

[29] B. Casentini, S. J. Hug, and N. P. Nikolaidis, "Arsenic accumulation in irrigated agricultural soils in Northern Greece," Science of the Total Environment, vol. 409, pp. 4802-4810, 2011.

[30] S. Bhattacharya, K. Gupta, S. Debnath, U. C. Ghosh, D. Chattopadhyay, and A. Mukhopadhyay, "Arsenic bioaccumulation in rice and edible plants and subsequent transmission through food chain in Bengal basin: a review of the perspectives for environmental health," Toxicological and Environmental Chemistry, vol. 94, no. 3, pp. 429-441, 2012.

[31] S. K. Acharyya, S. Lahiri, B. C. Raymahashay, and A. Bhowmik, "Arsenic toxicity of groundwater in parts of the Bengal basin in
India and Bangladesh: the role of Quaternary stratigraphy and Holocene sea-level fluctuation," Environmental Geology, vol. 39, no. 10, pp. 1127-1137, 2000.

[32] T. R. Chowdhury, G. K. Basu, B. K. Mandal et al., "Arsenic poisoning of Bangladesh groundwater," Nature, vol. 401, pp. 545-547, 1999.

[33] H. M. Anawar, J. Akai, T. Yoshioka et al., "Mobilization of arsenic in groundwater of Bangladesh: evidence from an incubation study," Environmental Geochemistry and Health, vol. 28 , no. 6, pp. 553-565, 2006.

[34] W. B. Achiba, N. Gabteni, A. Lakhdar et al., "Effects of 5-year application of municipal solid waste compost on the distribution and mobility of heavy metals in a Tunisian calcareous soil," Agriculture, Ecosystems and Environment, vol. 130, no. 3-4, pp. 156-163, 2009.

[35] S. S. Huang, Q. L. Liao, M. Hua et al., "Survey of heavy metal pollution and assessment of agricultural soil in Yangzhong district, Jiangsu Province, China," Chemosphere, vol. 67, no. 11, pp. 2148-2155, 2007.

[36] P. Zhuang, M. B. McBride, H. Xia, N. Li, and Z. Li, "Health risk from heavy metals via consumption of food crops in the vicinity of Dabaoshan mine, South China," Science of the Total Environment, vol. 407, no. 5, pp. 1551-1561, 2009.

[37] J. Liu, K. Li, J. Xu et al., "Lead toxicity, uptake, and translocation in different rice cultivars," Plant Science, vol. 165, no. 4, pp. 793-802, 2003.

[38] I. A. Katsoyiannis and A. A. Katsoyiannis, "Arsenic and other metal contamination of groundwaters in the industrial area of thessaloniki, Northern Greece," Environmental Monitoring and Assessment, vol. 123, no. 1-3, pp. 393-406, 2006.

[39] M. R. Beychok, "A data base of dioxin and furan emissions from municipal refuse incinerators," Atmospheric Environment. Part $A$, vol. 21, no. 1, pp. 29-36, 1987.

[40] "US EPA estimating risk from contaminants contained in agricultural fertilizers," Draft Report, Office of Solid Waste, US Environmental Protection Agency, 1999, http://www.epa.gov/epawaste/index.htm.

[41] G. C. Sigua, M. B. Adjei, and J. E. Rechcigl, "Cumulative and residual effects of repeated sewage sludge applications: forage productivity and soil quality implications in South Florida, USA," Environmental Science and Pollution Research, vol. 12, no. 2, pp. 80-88, 2005.

[42] J. W. C. Wong, K. L. Li, L. X. Zhou, and A. Selvam, "The sorption of $\mathrm{Cd}$ and $\mathrm{Zn}$ by different soils in the presence of dissolved organic matter from sludge," Geoderma, vol. 137, no. 3-4, pp. 310-317, 2007.

[43] S. Y. Selivanovskaya and V. Z. Latypova, "The use of bioassays for evaluating the toxicity of sewage sludge and sewage sludgeamended soil," Journal of Soils and Sediments, vol. 3, no. 2, pp. 85-92, 2003.

[44] K. Chander and P. C. Brookes, "Effects of heavy metals from past applications of sewage sludge on microbial biomass and organic matter accumulation in a sandy loam and silty loam U.K. soil," Soil Biology and Biochemistry, vol. 23, no. 10, pp. 927-932, 1991.

[45] X. Liu, S. Zhang, W. Wu, and H. Liu, "Metal sorption on soils as affected by the dissolved organic matter in sewage sludge and the relative calculation of sewage sludge application," Journal of Hazardous Materials, vol. 149, no. 2, pp. 399-407, 2007.

[46] S. Bozkurt, L. Moreno, and I. Neretnieks, "Long-term fate of organics in waste deposits and its effect on metal release," Science of the Total Environment, vol. 228, no. 2-3, pp. 135-152, 1999. 
[47] M. B. McBride, B. K. Richards, T. Steenhuis, and G. Spiers, "Long-term leaching of trace elements in a heavily sludgeamended silly clay loam soil," Soil Science, vol. 164, no. 9, pp. 613-623, 1999.

[48] A. Bhogal, F. A. Nicholson, B. J. Chambers, and M. A. Shepherd, "Effects of past sewage sludge additions on heavy metal availability in light textured soils: implications for crop yields and metal uptakes," Environmental Pollution, vol. 121, no. 3, pp. 413-423, 2003.

[49] M. J. Sánchez-Martín, M. García-Delgado, L. F. Lorenzo, M. S. Rodríguez-Cruz, and M. Arienzo, "Heavy metals in sewage sludge amended soils determined by sequential extractions as a function of incubation time of soils," Geoderma, vol. 142, no. 3-4, pp. 262-273, 2007. 

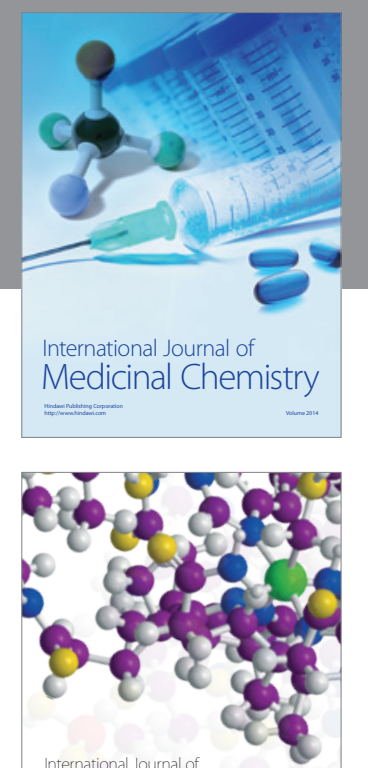

\section{Carbohydrate} Chemistry

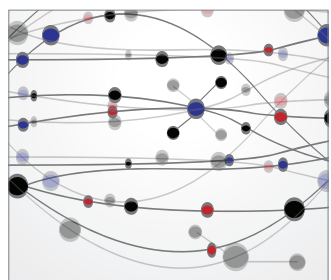

The Scientific World Journal
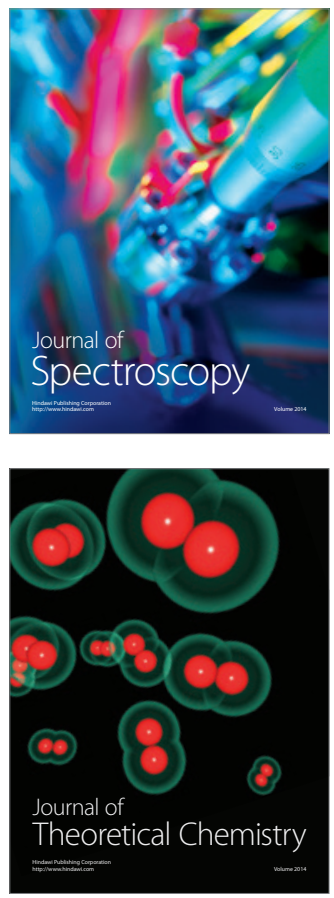
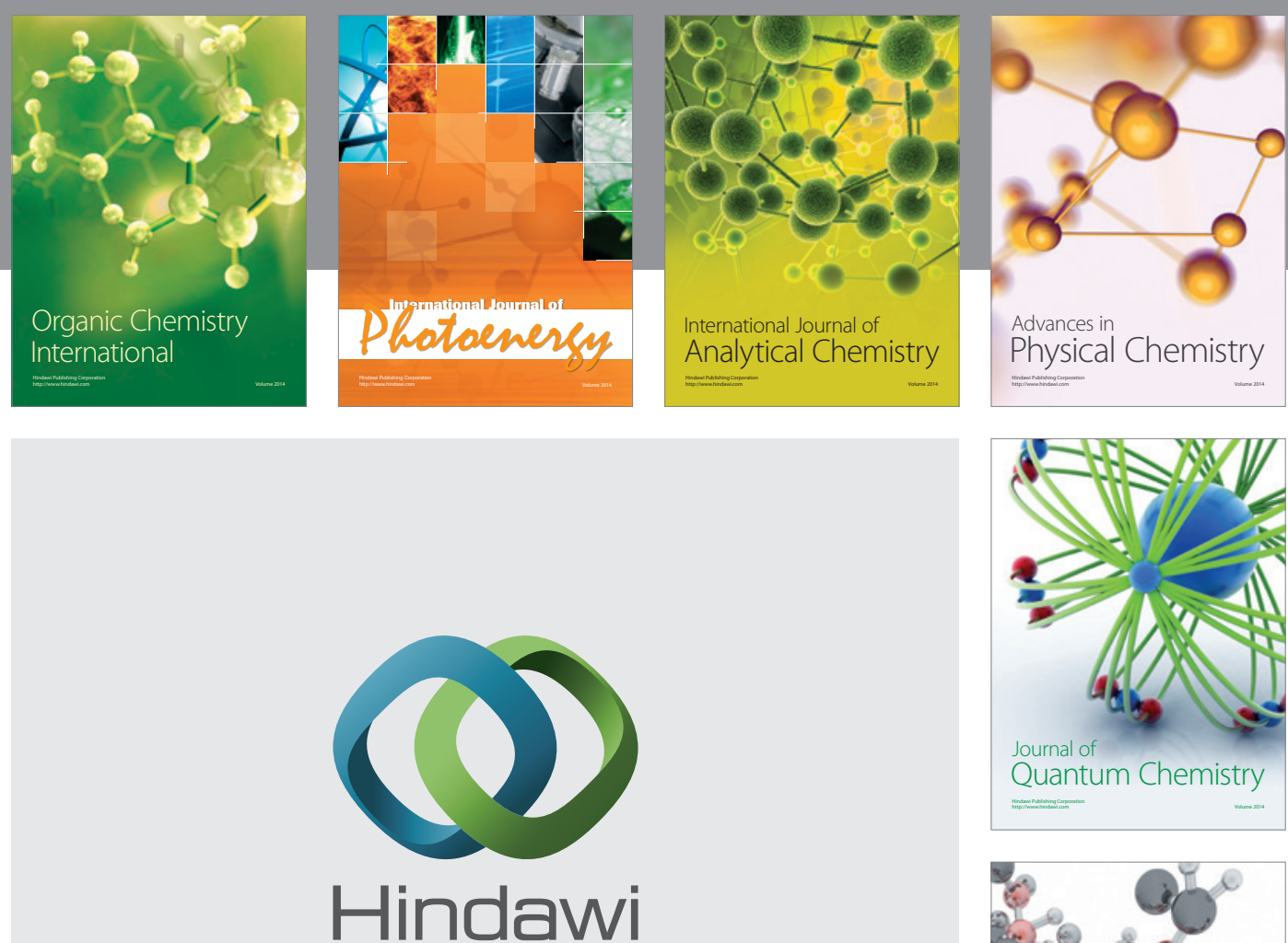

Submit your manuscripts at

http://www.hindawi.com

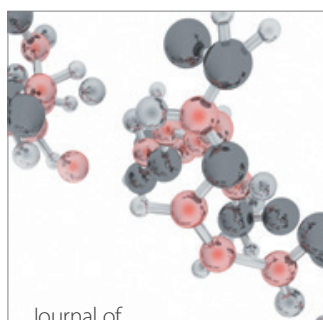

Analytical Methods

in Chemistry

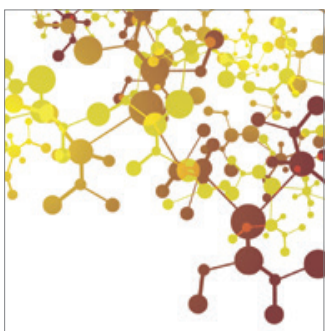

Journal of

Applied Chemistry

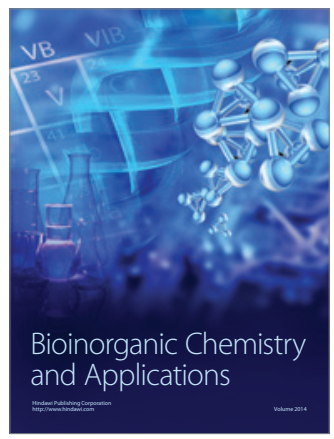

Inorganic Chemistry
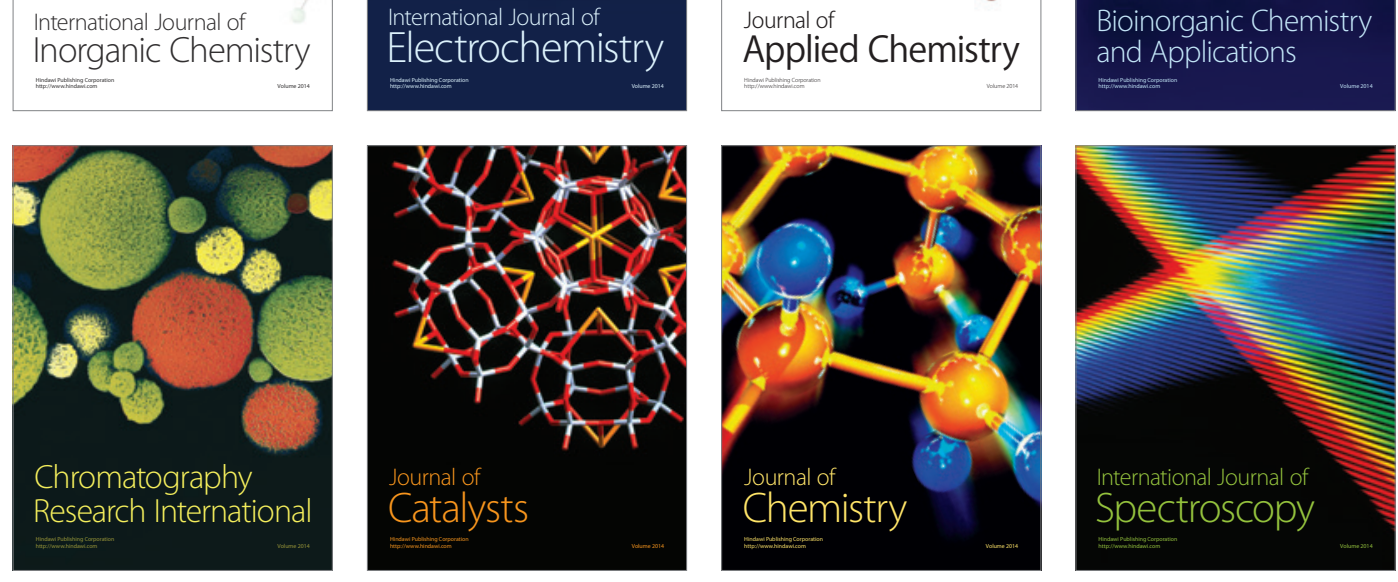